\title{
Perbandingan Hasil Belajar Siswa Melalui Penggunaan Media Poster Berbasis Ppt Interaktif dan Media Video Animasi pada Muatan IPS Kelas IV di SD
}

\author{
Yesita Galatia Maysella*, Syaiful Imam, Puri Selfi Cholifah \\ Universitas Negeri Malang, Jl. Semarang No. 5 Malang, Jawa Timur, Indonesia \\ *Penulis korespondensi, Surel: ymaysella@gmail.com
}

Paper received: 6-8-2021; revised: 20-8-2021; accepted: 28-8-2021

\begin{abstract}
This research was conducted with the aim of comparing the learning outcomes between students using PowerPoint-based poster learning media with animated video media in social studies subject class IV material "cultural diversity" at SDN Bunulrejo 02 Malang. This research is a quasiexperimental study with a population of all fourth grade students at SDN Bunulrejo 02 Malang. The sample in this study used a purposive sampling technique with 28 students in class IV A as the control class using PowerPoint-based poster media, while in class IV C, 28 students as an experimental class using animated video media. Data collection techniques in this study used the results of pre-test and posttest, interviews and documentation. The results of the study using the t-test obtained $t_{\text {count }}$ is 6.474 and ttable is 2.005 , so that the data with $\mathrm{t}_{\text {count }}$ greater than table, where $\mathrm{H}_{\mathrm{a}}$ is acceptable, and it is concluded that there is a significant comparison of student learning outcomes between the use of poster-based learning media and video learning media. animation on social studies learning material about cultural diversity.
\end{abstract}

Keywords: Powerpoint-based poster media; animated video media; social studies learning outcomes

\begin{abstract}
Abstrak
Penelitian ini dilakukan bertujuan guna melihat adanya perbandingan hasil belajar antara siswa yang menggunakan media pembelajaran poster berbasis powerpoint dengan media video animasi pada mata pelajaran IPS kelas IV materi "keragaman budaya" di Sekolah Dasar Negeri Bunulrejo 02 Malang. Penelitian ini merupakan penelitian quasi eksperimental dengan populasi seluruh peserta didik kelas IV SDN Bunulrejo 02 Malang. Sampel dalam penelitian menggunakan teknik purposive sampling dengan kelas IV A sebanyak 28 peserta didik sebagai kelas kontrol yang menggunakan media poster berbasis powerpoint adapun kelas IV C sebanyak 28 peserta didik sebagai kelas eksperimen yang menggunakan media video animasi. Teknik dalam pengumpulan data dalam penelitian menggunakan hasil tes pre-test dan posttest, wawancara serta dokumentasi. Hasil penelitian dengan menggunakan uji-t diperoleh thitung adalah 6,474 dan tabel adalah 2,005, sehingga data tersebut dengan thitung lebih dari tabel di mana $\mathrm{H}_{\mathrm{a}}$ dapat diterima, dan disimpulkan adanya perbandingan hasil belajar peserta didik yang signifikan antara menggunakan media pembelajaran poster berbasis powerpoint dengan media pembelajaran video animasi pada pembelajaran IPS materi keragaman budaya.
\end{abstract}

Kata kunci: media poster berbasis powerpoint; media video animasi; hasil belajar IPS

\section{Pendahuluan}

Pendidikan seperti yang tertera dalam Undang-Undang Nomor 20 tahun 2003 mengenai Sistem Pendidikan Nasional, menyatakan pendidikan merupakan suatu bentuk usaha secara terencana serta secara sadar dalam menciptakan suatu kondisi dalam proses pembelajaran sehingga mengaktifkan peserta didik dalam menumbuhkan kemampuan diri guna mempunyai kekuatan spiritual keagamaan, pengendalian diri, kepribadian, kecerdasan, akhlak mulia, serta 
keterampilan yang dibutuhkan untuk negara serta seluruh masyarakat. Sehingga pendidikan dianggap sebuah proses yang berkaitan dengan aktivitas dalam kehidupan yang berkelanjutan di lingkungan sekitar.

Pada tahun 2019 tepatnya akhir penghujung tahun, dunia mengalami pandemi Covid-19. Dalam rangka mencegah penyebaran Covid-19, dikeluarkannya kebijakan sesuai dengan Surat Edaran Nomor 3 Tahun 2020 oleh menteri pendidikan dan kebudayaan, dimana kebijakan ini diberlakukan mulai tanggal 16 Maret 2020, di mana banyak instansi pemerintah terutama sekolah-sekolah yang menyetujui untuk melakukan pembelajaran di rumah. Pembelajaran secara tatap muka tidak dapat dilakukan, namun pembelajaran tetap berlangsung hanya berbeda situasi yaitu pembelajaran dilakukan di rumah atau dikenal istilah pembelajaran secara daring. Adanya wabah virus Covid-19 inilah yang menyebabkan diberlakukannya kebijakan Work From Home (WFH). Serta kegiatan belajar di instansi pendidikan dilakukan secara daring. Dengan adanya kenyataan seperti ini yang membuat pandemi Covid-19 sangat terasa berpengaruh terhadap institusi pendidikan (Sudarsana, dkk, 2020).

Pendidik perlu mendesain pembelajaran daring efektif melalui penggunaan media daring yang dapat mempermudah pemahaman materi yang dipaparkan kepada peserta didik (Sudarsana, dkk 2020). Pendidik juga dituntut untuk mampu merancang sebaik mungkin mengenai apa saja cakupan materi dan media yang menopang menjadi penguatan metode belajar sehingga memudahkan dalam memahami materi. Keberhasilan pendidik dalam menciptakan pembelajaran daring Covid-19 ini didasarkan pada kemampuan pendidik dalam menciptakan rancangan metode belajar, pemilihan media yang sesuai dan mengumpulkan materi yang memiliki kecocokan satu dengan lainnya. Kunci kesuksesan seorang pendidik dalam memotivasi peserta didik agar semangat belajar secara daring ini adalah kreativitas. Sehingga peserta didik termotivasi belajar menyenangkan bukan menjadi beban psikis.

Mata pelajaran IPS memiliki tujuan yakni agar peserta didik memiliki potensi dalam menalar secara logis dan kritis, serta mempunyai kemampuan sosial. Kemampuan berpikir anak usia SD akan dapat terlatih apabila peserta didik mampu menyusun, merancang, mengelompokkan dan merangkum mengenai ide, pikiran, serta perasaan, terhadap orang lain secara lisan maupun tulisan. Saat melakukan kegiatan magang, peneliti menemukan bahwasanya pembelajaran IPS belum dapat dipahami dengan maksimal oleh peserta didik. Penyebab belum efektifnya pembelajaran IPS tersebut dikarenakan peserta didik yang belum bisa mengaitkan konsep-konsep dasar IPS dengan kehidupan sehari-hari, pelaksanaan pembelajaran yang diterapkan juga belum bervariatif dan kurang inovatif. Pendidik terkadang hanya berpacu pada buku paket dalam menjelaskan materi, dimana hal tersebut menjadikan kegiatan pembelajaran menjadi monoton. Materi IPS juga cukup banyak serta beragam juga membuat keterbatasan waktu pendidik dalam menyampaikan materi, di mana keadaan ini akan membuat pembelajaran IPS kurang efektif.

Berbagai permasalahan dalam pembelajaran IPS dapat diselesaikan dengan melalui pengembangan media yang tepat. Di mana pengembangan ini dapat meningkatkan kemampuan menalar, keaktifan belajar pada peserta didik sehingga dapat mempengaruhi peningkatan hasil belajar. Beberapa media yang mendukung antara lain media multimedia , media nyata dan gambar. Peneliti memilih penggunaan media pembelajaran audio-visual (media multimedia) dalam memecahkan permasalahan pembelajaran IPS. Penelitian difokuskan pada kelas IV SDN Bunulrejo 02 Malang pada materi keragaman budaya. Peneliti 
ingin membandingkan dari kedua media yang digunakan dalam penelitian yang memberikan pengaruh terhadap hasil belajar muatan IPS siswa kelas IV Sekolah Dasar Negeri Bunulrejo 02 Malang dengan menggunakan media pembelajaran audio-visual (media multimedia) dalam memecahkan permasalahan pembelajaran IPS, yaitu media poster yang disajikan dalam bentuk powerpoint interaktif serta media pembelajaran video animasi.

Media video dapat meningkatkan keaktifan peserta didik dalam proses pembelajaran. Penggunaan media video melibatkan beberapa indera peserta didik untuk memahami suatu materi yang diajarkan dengan memfokuskan perhatian mereka agar diarahkan ke media tersebut. Sesuai dengan penelitian yang dilakukan oleh Afridzal (2018) Mahasiswi STKIP Bina Bangsa Getsempena, melakukan penelitian dengan judul Perbedaan Hasil Belajar Menggunakan Media Gambar Dan Video Animasi Pada Materi Karangan Deskripsi Di Kelas III SD Negeri 28 Banda Aceh. Hasil dari penelitian tersebut menunjukkan adanya perbandingan hasil belajar peserta didik kelas III yang menggunakan media gambar berupa video animasi, dengan diperoleh hasil perhitungan pada penelitian dengan taraf signifikan sebesar 0,05 yaitu nilai sebesar 4,82 lebih besar dari nilai yaitu 1,67 di mana $\mathrm{H}_{0}$ ditolak dan $\mathrm{H}_{\mathrm{a}}$ diterima. Di mana peserta didik yang mengikuti pembelajaran dengan menggunakan video animasi lebih baik hasil belajarnya dikarenakan tujuan pembelajaran tercapai dengan maksimal sehingga peserta didik lebih memahami materi yang disampaikan. Tak hanya itu, media yang menggunakan powerpoint juga membuat pembelajaran lebih mudah dan menarik karena didukung tampilan tema powerpoint yang berwarna, sesuai dengan penelitian yang dilakukan oleh Nursyaida dan A. Hardiyanti (2020) dengan judul Efektivitas Penggunaan Media Powerpoint Terhadap Hasil Belajar IPS Kelas VSD 128 Turungan Beru Kecamatan Herlang Kabupaten Bulukumba, diperoleh kesimpulan nilai rata-rata peserta didik dengan menggunakan media powerpoint berkategori tinggi, di mana media powerpoint berpengaruh dalam peningkatan hasil belajar IPS peserta didik kelas V SD 128 Turungan Beru Kecamatan Herlang Kabupaten Bulukumba.

Berdasarkan penelitian terdahulu yang menyatakan bahwasanya kedua media yakni media video dan media powerpoint dinyatakan dapat memberi pengaruh pada peningkatan hasil belajar peserta didik, peneliti tertarik untuk melakukan penelitian mengenai perbandingan Hasil Belajar Siswa Melalui Penggunaan Media Poster Berbasis PPT Interaktif dan Media Video Animasi Pada Muatan IPS Kelas IV di Sekolah Dasar Negeri Bunulrejo 02 Malang.

\section{Metode}

Penelitian ini menggunakan jenis penelitian quasi experimental dengan desain pretestpostest Nonequivalent Control Group Design, yang terbagi menjadi dua kelompok yaitu kelompok kontrol dan eksperimen (Sugiyono, 2017). Adapun variabel dalam penelitian ini yaitu variabel independen dan dependen. Di mana media pembelajaran poster berbasis powerpoint dan media pembelajaran video animasi sebagai variabel independen. Sementara variabel dependen dalam penelitian yakni hasil belajar.

Penelitian dilakukan di Sekolah Dasar Negeri Bunulrejo 02 Malang beralamat di Jl. Bedadung No.03, kelurahan Bunulrejo, kecamatan Blimbing. SDN Bunulrejo 02 memiliki jenjang kelas 1 - kelas 6 dengan terbagi gologan kelas A, B, dan C dengan populasi berjumlah 84 peserta didik. Sampel dalam penelitian yang digunakan mencakup 2 kelas yakni kelas IV A sebanyak 28 peserta didik sebagai kelas kontrol yang menggunakan media poster berbasis powerpoint dan kelas IV C sebanyak 28 peserta didik sebagai kelas eksperimen yang 
menggunakan media video animasi. Pengambilan sampel menggunakan cara Nonprobability Sampling dengan teknik purposive sampling atau sampel bertujuan. Pengambilan sampel yang dilakukan peneliti berdasarkan data hasil wawancara yang diperoleh dari kepala sekolah mengenai kesamaan/ kesetaraan kemampuan belajar peserta didik kelas IV SDN Bunulrejo 02 Malang.

Instrumen pada penelitian berbentuk tes objektif berupa pilihan ganda yang berjumlah 15 soal. Instrumen digunakan sebagai alat ukur kemampuan hasil belajar pre-test serta posttest peserta didik di kelas kontrol maupun kelas eksperimen. Tahapan prosedur dalam penelitian menjadi 3 tahap sebagai berikut : (1) Tahap awal penelitian, meliputi penyusunan proposal, seminar proposal, menyempurnakan proposal, menyusun BAB I - BAB III serta instrumen penelitian melalui proses bimbingan dosen pembimbing, mengajukan izin penelitian dari Universitas Negeri Malang kepada Sekolah Dasar Negeri Bunulrejo 02 Malang, (2) Tahap pengumpulan data, meliputi kegiatan wawancara baik dilakukan kepada guru kelas IV A dan IV C, pemberian tes pre-test terhadap kedua kelas, melaksanakan proses pembelajaran menggunakan media yang telah ditentukan di kelas kontrol serta kelas eksperimen, (3) Tahap pengolahan data, meliputi melakukan uji test terhadap hasil yang diperoleh dari pre-test dan posttest kedua kelas.

Sebelum dilakukan pengujian hipotesis, peneliti melakukan validitas dan reliabilitas terhadap instrumen yang akan digunakan untuk menemukan instrumen manakah yang layak dipakai sebagai uji saat penelitian. Instrumen yang memiliki kategori layak digunakan dalam penelitian selanjutnya dilakukan analisa data menggunakan uji normalitas dan uji homogenitas, dan uji t - test. Analisa data dilakukan guna mengetahui adanya perbandingan hasil belajar dari penggunaan media poster berbasis powerpoint dan media video animasi pada bahan ajar IPS Kelas IV SDN Bunulrejo 02 Malang.

\section{Hasil dan Pembahasan}

Berdasarkan penelitian yang dilakukan terhadap peserta didik kelas IV A dan IV C SDN Bunulrejo 02 Malang terhadap pembelajaran IPS menggunakan media poster berbasis powerpoint dan media video animasi pada materi keragaman budaya, diperoleh hasil analisis data posttest dengan berbantuan software SPSS 26 for windows pengujian normalitas menggunakan uji Kolmogorov-Smirnov Z pada kelas kontrol dan eksperimen kelas IV SDN Bunulrejo 02 Malang memiliki sebaran data yang normal sesuai dengan ketentuan nilai Sig > 0,05 sehingga dinyatakan data kedua kelas berdistribusi normal sesuai dengan penjabaran tabel berikut.

Tabel 1. Output Uji Normalitas Instrumen Penelitian Post-test

\begin{tabular}{llcc}
\hline Hasil Pengujian & & Posttest Eksperimen & Posttest Kontrol \\
\hline $\mathrm{N}$ & & 28 & 28 \\
Normal Parametersa,b & Mean & 86,82 & 68,43 \\
& Std. Deviation & 9,117 & 11,955 \\
Most Extreme Differences & Absolute & 0,144 & 0,155 \\
& Positive & 0,143 & 0,152 \\
& Negative & $-0,144$ & $-0,155$ \\
Test Statistic & & 0,144 & 0,155 \\
Asymp. Sig. (2-tailed) & & $0,144 \mathrm{c}$ & $0,084 \mathrm{c}$ \\
Test distribution is Normal. & & \\
\hline
\end{tabular}


Tahap selanjutnya melakukan uji homogenitas, bertujuan guna mengetahui data sampel yang akan diuji berhomogen atau tidak. Tak hanya itu, uji homogenitas sebagai syarat pemenuhan pada uji-t. Perhitungan uji homogenitas pada kedua kelas yang diteliti memperoleh hasil bahwa kedua sampel memiliki nilai Sig uji homogenitas yakni 0,070 , di mana nilai Sig > dari 0,05 sehingga dinyatakan kedua sampel ber homogenitas dan memiliki syarat untuk melakukan uji t-test sesuai dengan penjabaran pada tabel berikut.

Tabel 2. Hasil Uji Homogenitas

\begin{tabular}{|c|c|c|c|c|c|}
\hline \multicolumn{3}{|c|}{ Levene Statistic } & df1 & df2 & Sig. \\
\hline \multirow[t]{4}{*}{ Hasil Belajar } & Based on Mean & 3,405 & 1 & 54 & 0,070 \\
\hline & Based on Median & 2,893 & 1 & 54 & 0,095 \\
\hline & Based on Median and with adjusted df & 2,893 & 1 & 52,485 & 0,095 \\
\hline & Based on trimmed mean & 3,473 & 1 & 54 & 0,068 \\
\hline
\end{tabular}

Langkah terakhir yaitu melakukan uji t-test, bertujuan guna untuk mengetahui perbedaan hasil belajar dari kedua kelas yang digunakan sebagai sampel penelitian. Penghitungan uji memakai statistic Independent Sample T-Test equal variances assumed dengan patokan yakni $t_{\text {hitung }}>t_{\text {tabel }} \mathrm{H}_{\mathrm{o}}$ ditolak dan $\mathrm{H}_{\mathrm{a}}$ diterima. Berdasarkan perhitungan yang dilakukan, didperoleh hasil nilai sebesar 6,474 sedangkan nilai sebesar 2,005 signifikansi 0,05 diperoleh $>(6,474>2,005)$ di mana $\mathrm{H}_{a}$ dapat diterima, sehingga disimpulkan adanya perbandingan hasil belajar peserta didik yang menggunakan media pembelajaran poster berbasis powerpoint dengan media pembelajaran video animasi dalam pembelajaran IPS tentang "keragaman suku dan budaya" yang mempengaruhi hasil belajar peserta didik kelas IV. Adapun nilai rerata yang diperoleh kelas eksperimen lebih besar dari nilai rerata kelas kontrol $(86,82>68,42)$, sehingga dinyatakan pembelajaran yang memakai media video animasi memperoleh hasil belajar lebih tinggi daripada pembelajaran yang memakai poster berbasis PPT Interaktif.

\section{Simpulan}

Berkaitan pada hasil serta pembahasan, dapat disimpulkan pembelajaran IPS menggunakan media video animasi memiliki pengaruh baik terhadap hasil belajar peserta didik kelas IV dibandingkan media poster berbasis powerpoint, di mana sesuai hasil yang signifikan rerata post-test peserta didik kelas eksperimen lebih tinggi dari rerata kelas kontrol $(86,82>68,42)$. Melalui hasil perhitungan uji-t, didapatkan thitung sebesar 6,474 lebih besar dari $2,005\left(t_{\text {tabel }}\right)$ yang menunjukkan adanya perbedaan hasil belajar.

\section{Daftar Rujukan}

Afridzal, A. (2018). Perbedaan Hasil Belajar Menggunakan Media Gambar Dan Video Animasi Pada Materi Karangan Deskripsi Di Kelas III Sd Negeri 28 Banda Aceh. Jurnal Tunas Bangsa, 5(2), 231-247.

Arikunto, S. (2012). Prosedur Penelitian. Jakarta: Rineka Cipta.

Dewi, P.K. \& Budiana, N. (2018). Media Pembelajaran Bahasa: Aplikasi Teori Belajar dan Strategi Pengoptimalan Pembelajaran. Malang: UB Press.

Dimyati \& Mudjiono. (2006). Belajar dan Pembelajaran. Jakarta: PT Rineke Cipta.

Kemendikbud. (2020) Surat Edaran Kemendikbud No. 3 tahun 2020. Pelaksanaan Pencegahan Corona Virus Disease (COVID-19).

Nursyaida, N., \& Hardiyanti, A. (2020). Efektivitas Penggunaan Media Power Point Terhadap Hasil Belajar Ips Kelas V Sd 128 Turungan Beru Kecamatan Herlang Kabupaten Bulukumba. JRPD (Jurnal Riset Pendidikan Dasar), 3(1), 71-76. 
Jurnal Pembelajaran, Bimbingan, dan Pengelolaan Pendidikan, 1(8), 2021, 682-687

Septiana, N. (2019). ICT Dalam Pembelajaran MI/SD. Pamekasan: Duta Media Publishing.

Susanto, A. (2016). Pengembangan Pendidikan IPS SD. Surakarta: Direktorat Jenderal Pendidikan Tinggi Departemen Pendidikan Nasional.

Sugiyono. (2017). Metode Penelitian Kuantitatif, Kualitatif, dan R\&D. Bandung: Alfabeta, CV.

Yuliani, M., Simarmata, J., Susanti, S.S., Mahawati, E., Sudra, R.I., Dwiyanto, H., Irawan, E., Ardiana, D.P., Muttaqin, \& Yuniwati, I. (2020). Pembelajaran daring Untuk Pendidikan: Teori dan Penerapan. Medan: Yayasan Kita Menulis. 